\title{
émulations
}

\section{Because the Night Belongs to Us}

\section{Jordi Nofre}

Émulations - Revue de sciences sociales

2020, $n^{\circ} 33$, «La nuit urbaine. Un espace-temps complexe entre opportunités et inégalités ».

\section{Article disponible à l'adresse suivante}

https://ojs.uclouvain.be/index.php/emulations/article/view/nofre

\section{Pour citer cet article}

Jordi Nofre, «Because the Night Belongs to Us », Émulations, $n^{\circ} 33$, Mise en ligne le 15 juin 2020.

DOI : 10.14428/emulations.033.08

Distribution électronique : Université catholique de Louvain (Belgique) : ojs.uclouvain.be

(C) Cet article est mis à disposition selon les termes de la Licence Creative Commons Attribution, Pas d'Utilisation Commerciale 4.0 International. http://creativecommons.org/licenses/by-nc/4.0/

Éditeur : Émulations - Revue de sciences sociales / Presses universitaires de Louvain https://ojs.uclouvain.be/index.php/emulations

ISSN électronique : 1784-5734

PUL PRESSES

UNIVERSITAIRES 


\title{
Because the Night Belongs to Us
}

Jordi Nofre

\begin{abstract}
[Abstract] This text is an epilogue to this special issue, where topics addressed by its different contributors are of a great scientific interest towards more profound understanding about the urban night in both the Global North and South. As will be argued below, this special issue allows us to confirm two fundamental issues for the development of « Night Studies » in the next years. Firstly, the night often exacerbates the range of inequalities not only in the Western world but in non-Western cities. And, secondly, the night remains as an underexplored terrain, and, therefore, there is still a long path to walk.
\end{abstract}

Keywords: epilogue, night studies, underexplored terrain.

\section{Parce que la nuit nous appartient}

[Résumé] Ce texte est un épilogue à ce numéro spécial, où les sujets abordés par les différents contributeurs sont d'un grand intérêt scientifique pour une compréhension plus approfondie de la nuit urbaine dans le Nord et le Sud globaux. Comme nous le verrons plus loin, ce numéro spécial nous permet de confirmer deux questions fondamentales pour le développement des « études nocturnes » durant les prochaines années. Premièrement, la nuit exacerbe souvent les inégalités, non seulement dans le monde occidental, mais aussi dans les villes non occidentales. Deuxièmement, la nuit reste un terrain sous-exploré. Par conséquent, le chemin reste encore long à parcourir.

Mots-clés : épilogue, études nocturnes, terrain sous-exploré.

\section{Introduction}

In 30th November 1977, Patti Smith and Bruce Springsteen first performed Because the Night at CBGB's in New York City, one of the most legendary music clubs of the Neoyorkian punk and new wave scene. In that time, the city's bankruptcy, high crime rates linked to the violence of the drug epidemic, vast building degradation, and a dramatic population loss that vacated central areas of the city led many people to see New York as a city that was burning - paraphrasing Jonathan Mahler's book The Bronx is Burning (1977). In particular, crime, drug gangs, sexual exploitation, an incipient patriarchal porno industry and their multiple gritty intersections characterised Times Square in late 1970s. However, as brilliantly shown by David Simon and George Pelecanos HBO serie The Deuce (2017), Times Square was the first place in the Global North where the night-time leisure economy appeared as mechanism and strategy to change the face of today's most visited places in New York city.

\footnotetext{
${ }^{1}$ Interdisciplinary Centre of Social Sciences, Faculty of Social \& Human Sciences, NOVA University of Lisbon, Portugal. This work was supported by the Portuguese Foundation for Science \& Technology (CEECIND/01171/2017; PTDC/ART-PER/32417/2017; PTDC/SOC-SOC/28655/2017), and the Interdisciplinary Centre of Social Sciences at NOVA University of Lisbon.
} 
At the same time that a renovated commercial nightlife emerged as catalysers of urban, social, and cultural change in central New York, Madrid's movida ${ }^{2}$ and Lisbon's movida in earlier and mid-1980s emerged as new nocturnal scenes in which music, culture, arts and politics merged as a synonym of cultural, sexual and even political individual and collective liberation after four decades of fascist dictatorship in both Iberian countries. Also in earlier 1980s, nightlife was central in the emergence of the Yugo-rock scene in the main Yugoslavian cities (e.g. Belgrade, Sarajevo, Split, and Zagreb) that meant a significant (youth) cultural and even political revolution after the death of Josip Tito (Petra-Ramet, 2018 ; Čengić, Martin-Diaz, 2018). And coming back again to the Iberian Peninsula, the birth of makina music in eastern Spain meant a rapid metropolitanisation of night-time leisure practises since late 1980s (Ginesi, 2013; Costa, 2016), while it also meant a huge step forward in the construction of Ibiza Island as a world nightlife resort (Brewster, Broughton, 2014 ; Costa, 2016). In turn, and also in the late 1980s, some former industrial spaces in eastern Berlin were transformed into some of today's most famous techno music clubs across Europe (and overseas).

The evolution of nightlife in New York, Madrid, Lisbon, Ibiza and Berlin over these past four decades shows us that the geographical origin of the concept «night-time leisure economy » should be located out of United Kingdom and one decade before of the launch of Comedia Consultancy's report Out of Hours: A Study of Economic, Social and Cultural Life in Twelve Town Centres in the UK ${ }^{3}$ about how to revitalise socioeconomically degraded central urban areas of the 1980s' British cities and towns. Fortunately, the consensus that the expansion of nightlife as mechanism and strategy of urban renewal and socioeconomic revitalisation in degraded central areas of European post-industrial cities was born in United Kingdom in the late 1980s (Bianchini, 1990, 1995 ; Lovatt, O'Connor, 1995 ; Chatterton, Hollands, 2003 ; among dozens others), has recently known new academic inputs from non-anglophone countries, especially from peripheral Europe and other regions of the world, especially from Eastern Mediterranean region, the Americas and Asia (Buchakjian, 2015 ; de Góis, 2015 ; MacArthur-Seal, 2017).

In fact, the importance of exploring the night in Asia is crucial for us scholars of « Night Studies » in order to provide knowledge about, among other issues, the complex interplay between tradition, westernised youthful hedonism, embodied state control and capitalism in the development of night-time urban leisure. As Su-Jan Yeo et al. (2016:383) argue, « nightlife in contemporary Asian cities [...] are shifting toward more globalised forms of entertainment spaces similar in nature to existing trends in Europe and North America. At the same time, however, these Asian cities espouse culturally distinctive urban practices, revealing space-time geographies that are markedly different from nightlife experiences in the West ». Although some works about nightlife in

\footnotetext{
${ }^{2}$ In fact, there were many movidas across 1980s' Spain, especially in small cities and towns of the country such as in Vigo, Gijón, Bilbo, Iruña, Zaragoza, among many others.

${ }^{3}$ Comedia Consultancy (1991), "Out of Hours: A Study of Economic, Social and Cultural Life in Twelve Town Centres in the UK - Summary Report », London, Comedia Consultancy and Calouste Gulbenkian Foundation.
} 
Hanoi (Vietnam), Jakarta (Indonesia), Kuala Lumpur (Malaysia), Phuket (Thailand) and Tokyo (Japan) have been published over these last two decades and half by especially focusing on migrants and sexual workers (Allison, 1994 ; Parrenas, 2006 ; Hilsdon, 2007; Ph ng, 2011), the case of nightlife in Chinese cities deserves our special attention. In this sense, here we must mention two seminal works. Namely James Farrer and his ethnography about how urban Chinese youth participate in the cosmopolitan sexual culture of the discotheque, using the hybrid cultural space of the discotheque for their own forms of sexual display and interaction (Farrer, 1999) ; and Andrew David Field's (2001) work on the influence of nightlife on Chinese politics and social life in the city of Shanghai between the two world wars. Also Farrer (2008) brilliantly argued that nightlife appears as an important space for the study of Chinese social stratification and the study of sexual subcultures in Chinese cities. For the author, nightlife emerges as a privileged area in which one can study « the transnational processes of cultural change in China, while examining the possibilities of individual agency, resistance and creativity within these organizing structures » (Farrer, 2008: 1). More recently, new works have highlighted the expansion of Western(ised) night-time leisure economy in urban China (Chongyi, 2007 ; Chew, 2009 ; Zeng, 2009; Song et al., 2016).

Undoubtedly, growing knowledge on the urban night in non-Western cities is crucial in order to not simply « contest » academic Anglodominance - which would be even counterproductive in regard to the goal of widening, spreading and sharing scientific knowledge among us, the "Night Studies » scholars - but also regarding the range of new opportunities of collaborations to deepen our knowledge about the 'What's, the 'Who's, the 'Why's and the 'How's of the vibrant, exciting and multifaceted nights in cities in the past, in the present, and in the future.

\section{A timely and convenient special issue}

This special issue entitled The Urban Night: A Complex Space-time Amidst Opportunities and Inequalities appears at the best time it could do it. In recent years, a growing number of scholars have begun to pay attention to the range of social, spatial, cultural, economic and even political phenomena that take place in the "Nocturnal City " (Shaw, 2018). The number of topics addressed in this brilliant special issue highlight how necessary transdisciplinarity is in order to capture the whole complexity and very complex range of phenomena currently taking place in the urban night across the world. By taking Beirut (Lebanon), Dakar (Senegal), Lisbon (Portugal) and three French cities (Marseille, Paris, and Montpellier), this collection of articles explores topics that count with a vibrant current development within the field of "Night Studies " (Hollands, 2015 ; Nofre, Eldridge, 2018 ; Kyba et al., 2019). Some of the topics show a consolidated epistemological trajectory, such as the relationship between Night-Time Economy (NTE) and urban policies; noise and light pollution; conflicts between different local actors (residents, patrons and venues' owners); institutional and/or community response to such conflicts; and inequalities inflected by class, gender, age, geographic and/or natio- 
nal origin, cultural background, religion and its multiple intersections. Interestingly, some authors deal with little explored topics, but of a huge scientific interest, such as new work methodologies, temporary urbanism, and invisibilized domestic work.

This special issue ends with a methodological reflection about researching (in) the urban night. In her brilliant article, Marie Bonte takes Anne Volvey, Yann Calbérac et Myriam Houssay-Holzschuch's (2012) work about the reflexive transformation of the field into an epistemological object in order to suggest « the nocturnal terrain » as an object of epistemological reflection. In doing so, Bonte opens up a wide range of still-not-explored questions about researching (in) the night in non-western countries. First of all, the unequal development of « Night Studies » in the Global North and the Global South since the institutionalisation of scientific disciplines has favoured (and still favours) the employment (consciously or unconsciously) of theoretical-conceptual frameworks developed in Western capitalist contexts that can make difficult a proper understanding of the complex, non-linear and often multiple meanings of nocturnal activities in the urban world of, for example, the African or Asian continent. Concepts such as " youth », " time » or " safety " are extremely different according to different cultural, social, political and even economical approaches to such concepts. Yet interestingly, Bonte remarks the urgent need in making visible the range of difficulties, fears and insecure situations experienced by women researchers in (often patriarchal) nightlife settings.

In this sense, Thomas Fouquet, in the second paper of this special issue about uncertainty and indetermination in the urban night of Dakar in Senegal, provides us an outstanding example of the importance of building new Epistemologies of the South - in terminology of Anibal Quijano (2000) and Boaventura de Sousa Santos (2010) - in the field of « Night Studies ». In fact, « uncertainty » could be seen as an intrinsic part of what the Byelorussian journalist Ryszard Kapuściński defines as " African time " - which is made by the human activity in contrast to the mathematical, Cartesian European time. If it is understood so, one could argue that « uncertainty » could be equivalent, in some way, to the informality that has traditionally characterised the African urban world to date. However, " uncertainty " and " indetermination » can also be seen as dispositive of neoliberal governmentality in the post-/neo-colonial African cities that have harsh effects especially among lower-class youth. That is why we " night scholars " need further studies in order to deepen in the understanding of the relationships between (i) both local and (post-)/(neo-)colonial nights in non-Western contexts by, at the same time, shedding light on the intense dialogue between the (de-)colonisation and the (neo-)colonisation of knowledge about the night in the Global South.

In some way, uncertainty also features everyday life of working-class baby mothers in the global urban world. By taking the 15th district of Marseille (France), Arianna Cecconi explores the urban night of this working-class neighbourhood by examining how daily dreaming practices of baby mothers of this study area are inflected by ma- 
terial, cultural, and even environmental inequalities. In doing so, Cecconi examines the interplay between the night, dreaming, precarity and space. This is of fundamental importance for shedding light on baby caring as invisible (or invisibilised) productive activities not only in 21st century Global North but also (and especially) in the Global South. Night-time domestic work such as baby caring (still extremely feminised as a patriarchal/institutional imposition across the world) deserves all our attention since, whether the night has been formally recognized as a productive time-space of our global cities, there are still invisible/invisibilised activities that need to be not only socially recognized but also politically addressed as central elements of social wellbeing and equality in our diverse societies.

However, ambivalence and contradictions do not only feature the institutional gaze about nighttime domestic work, but also the range of interventions that many local administrations have carried out by fuelling nightlife as a catalyst of urban regeneration and socioeconomic revitalisation of formerly central areas of many cities worldwide. By taking Lisbon (Portugal) and Montpellier (France) as cases studies in the fourth paper of this special issue, Emanuele Giordano and Pedro Gomes examine how the expansion of tourist-oriented, college student-oriented nightlife in central areas of both cities has not been accompanied by the integration of « nocturnal temporalities » in their urban planning and policies deployed along the past years. As result of this, such an absence has led to the rise of conflicts between different local actors of the night (venues' owners, partygoers, residents, municipals) and, therefore, to the worsening of community liveability. In this sense, the promotion of a new generation of urban planning and policies that could integrate the different nocturnal temporalities of our cities would mean a huge step forward in the defence of the Right to the City. The two authors also remark that the absence of such integration in the cases of Lisbon (Portugal) and Montpellier (France) has indeed led to the emergence of a conflictual coexistence between leisure and residential functions in specific quarters of both cities. In a forthcoming article written with my LXNIGHTS ${ }^{4}$ colleagues João Carlos Martins and Cristiana Pires, I suggest that such a conflictual coexistence may be understood as an « unresolved clash of rights ».

However, commercial (or « capitalist ») nightlife is being increasingly contested in many cities worldwide. In France, Gwenaëlle Dourthe and Alexandre Grondeau introduce us the Free Party Movement, which promotes alternative nightlife spaces as political contestation to commercial nightlife of French cities, in which the night is highly marked by race and class discrimination. These alternative nightlife spaces are called "Temporary Autonomous Zones ». The authors argue that such zones are created in urban interstices, squattered spaces and/or peripheral areas of the city, appearing as exciting, vibrant initiatives that radically challenge the expansion of commodified nightlife activities, which are increasingly marked by oppression and violence against

${ }^{4}$ LXNIGHTS - The International Research Network on the Urban Night (URL: http://https://www. Ixnights.pt/). 
minorities and women. This is indeed a very interesting article in which Gwenaëlle Dourthe and Alexandre Grondeau make us recall that nightlife can also be a source of social wellbeing, inclusion, community-building and integration. However, these concepts can be extremely and critically jeopardised by the range of negative impacts derived from the expansion of nightlife activities in sensible urban areas of our cities. This is what Adrien Defrance argues for the case of Jean-Pierre Timbaud Street in Paris and the increasing noise pollution caused by nightlife venues and their patrons chatting loudly outdoors at late night and beyond. However, this brings here a critical question regarding the arrival of newcomers and/or gentrifiers to traditional nightlife spots of the city: What is the legitimacy of newcomers in complaining against the presence of nightlife in their « new " neighbourhood? This is a very provocative question that does not pretend to obtain an immediate answer. In fact, this question aims at remarking the urgent need in examining and assessing the impacts of the touristification of the night in our cities.

\section{Researching (in) the urban night in the 2020 s and beyond}

The topics addressed in this special issue on the urban night are of a great scientific interest towards more profound understanding about the urban night in both the Global North and South. In fact, this special issue allows us to confirm two fundamental issues for the development of « Night Studies » in the next years. Firstly, the night often exacerbates the range of inequalities not only in the Western world but in non-Western cities. And, secondly, the night remains as an underexplored terrain, and, therefore, there is still a long path to walk. In other words, beyond the role of night-time leisure economy in transforming central areas of our cities and, more recently, the range of impacts derived from the touristification of the urban night, there are several other topics that deserve our attention due to their simultaneous invisibility in the academic sphere and their importance for a better understanding of the "Nocturnal City (Shaw, 2018).

The first topic that must be urgently addressed relates to the absence of specific ethical regulation regarding the collection, treatment, use and re-use of data provided by informants with a state of drunkenness and/or under effects of psychoactive substances. Indeed, ethnography (observation and/or interviews in situ) with partygoers under the effects of alcohol and/or drugs raises some questions about ethical aspects of ethnographic research conducted in nightlife contexts. In particular in the European academic sphere, it is urgently needed more clarification about the validity of data provided by « drunken » and/or drugged informants, since regulation (EU) 2016/679 on the protection of natural persons with regard to the processing of personal data and on the free movement of such data (including the corrigendum published in the OJEU of 23 May 2018) does not enclose properly which are «the limits » for the use of such an ethnographic information. We « Night Studies » scholars should make a joint effort in proposing a step forward in this issue of enormous importance for our future research. 
Another topic of paramount interest for us « Night Studies » scholars is the role of the wide and intense use of social media among (not only) adolescents and teenagers in the reconfiguration of their night-time leisure practises. Social media as leisure culture (Albrechtslund, Albrechtslund, 2014) especially during evening and night-time hours at domestic space has an impact on the development of their night-time leisure practises. In turn, ongoing fieldwork conducted by some LXNIGHTS members have gathered serious concerns of many venues' owners in regard to the decrease of patrons in relation to ten or fifteen years ago. Many of them blame the crisis. However, some of them notes the importance of taking the boom of mobile dating apps among young adults and adults as a central element that has led to the drop of the number of people clubbing. If, once upon a time, the night was the promise land for seduction, mobile dating apps have dethroned. Swiping right is much cheaper than clubbing.

In parallel to the expansion of mediated dating during night-time leisure hours of young adults and adults, here we must mention another research topic that should be addressed in the next years by « Night Studies » scholars. As Kristine Vaadal (2019) points out, mainstream nightlife has traditionally been a space marked by compulsory (hetero) sexuality and heteronormativity, making it a key arena for gendered power relations and episodes of sexual harassment. At long last, and hopefully forever, sexual violence, harassment and other patriarchal attitudes that have been long tolerated institutionally during night-time leisure practises in both private and public premises, have begun to be contested by a range of different social actors. In fact, it should not be forgotten that women's fight for safer and sexism free nights in global cities is simultaneously intersected by (self-)empowered actions against patriarchal commercial nightlife, racism and xenophobia during night-time leisure spaces.

With no doubt, the urban night has recently emerged as an exciting scholar field, although enormous challenges are jeopardising its normal evolution towards a consolidated interdisciplinary field. While, in a recent article Kyba et al. (2019) argue that further networking and institutionalisation of « Night Studies » is urgently needed in order to develop into a recognized interdisciplinary field, here some other « hidden aspects » of the academy should be highlighted as major threats for the development of the interdisciplinary field of "Night Studies». On the one hand, nightlife is still considered as a synonym of vice, sin and immorality at the institutional level in most countries across the world. This perverse vision about the night is also shared by many young and old scholars who belong to conservative (even reactionary) forces (although they are often deftly camouflaged as « leftists ») that, at the same time, have strengthened their presence in many universities in Europe and overseas. On the other hand, the interdisciplinarity that Kyba et al. (2019) appeal for the field of « Night Studies » seems to replicate traditional, rigid and even sometimes protectionist disciplinary division of sciences. However, these current times of global illiberalism (Reed, 2019), and growing repression against women, ethnic and sexual minorities and other vulnerable groups, demands, with special emphasis on urban contexts from both Global North and South, 
the adoption an interdisciplinary approach based especially on queer, postcolonial/ decolonial, intersectional and feminist approaches that does neither appear in Kyba et al. (2019). This is only possible if we break the male-dominated, patriarchal, heteronormative academy.

Finally, and yet importantly, I would not like to end up this epilogue without mentioning another important aspect of this special issue about the urban night that has to do with the often-suspicious relationship that have defined the scarce academic debate between French and British social and human sciences since its institutionalisation in the nineteenth century. In particular in the field of " Night Studies », both French and British scholar worlds have turned their back on themselves for many decades until recent dates. Hopefully, a growing number of works have begun to merge both epistemological backdrop. This is the main reason why this special issue appears as one of the most important contributions in the field of Night Studies in the beginning of this new decade.

\section{Bibliography}

Albrechtslund A. M. B., Albrechtslund A. (2014), « Social Media as Leisure Culture », First Monday, vol. 19, $\mathrm{n}^{\circ}$ 4. Online, accessed 2 February 2020. URL: https://journals.uic. edu/ojs/index.php/fm/article/view/4877/3867.

Allison A. (1994), Nightwork: Sexuality, Pleasure, and Corporate Masculinity in a Tokyo Hostess Club, Chicago, University of Chicago Press.

Bianchini F. (1990), " The Crisis of Urban Public Social Life in Britain: Origins of the Problem and Possible Responses », Planning Practice and Research, vol. 5, n 3, p. 4-8.

Bianchini F. (1995), « Night Cultures, Night Economies », Planning Practice and Research, vol. 10, $\mathrm{n}^{\circ}$ 2, p. 121-126.

Brewster B., Broughton F. (2014), Last Night a DJ Saved My Life: The history of the disc jockey, New York, Headline Book Publishing.

Buchakjian G. (2015), « Beirut by Night: A Century of Nightlife Photography », Middle East Journal of Culture and Communication, vol. 8, n² 2-3, p. 256-281.

Čengić N., Martin-Diaz J. (2018), « Night-time Economy and Urban Development in Postsocialist Sarajevo », in J. Nofre, A. EldRIDGE (eds), Exploring Nightlife: Space, Society er Governance, London, Rowman \& Littlefield International, p. 53-67.

Chatterton P., Hollands R. (2003), Urban Nightscapes: Youth Cultures, Pleasure Spaces and Corporate Power, London, Routledge.

CHEw M. M. (2009), « Research on Chinese Nightlife Cultures and Night-time Economies: Guest Editor's Introduction », Chinese Sociology \& Anthropology, vol. 42, n 2, p. 3-21.

Chongyi F. (2007), «From Barrooms to Teahouses: Commercial Nightlife in Hainan since 1988 », in J. WANG (ed.), Locating China: Space, Place, and Popular Culture, New York, Routledge, p. 147-163. 
Costa L. (2016), ¡Bacalao!: historia oral de la música de baile en Valencia, 1980-1995, Barcelona, Contraediciones.

FARRER J. (1999), « Disco "Super-Culture”: Consuming Foreign Sex in the Chinese Disco Cosmopolitan Dance Culture and Cosmopolitan Sexual Culture », Sexualities, vol. 2, $\mathrm{n}^{\circ} 2, \mathrm{p} .147-165$.

FARRER J. (2008), « Play and Power in Chinese Nightlife Spaces », China: An International Journal, vol. 6, $\mathrm{n}^{\circ}$ 1, p. 1-17.

FIELD A. (2001), A Night in Shanghai: Nightlife and Modernity in Semicolonical China, 19191937, PhD dissertation, New York, Columbia University.

Górs M. P. F. de (2015), « Na Calada da Noite: Modernidade e Conservadorismo na Vida Noturna Carioca (1760-1950) », Espaço Aberto, vol. 5, nº 2, p. 49-60.

Ginesi G. (2013), « !Baila toda la noche! », in S. Martínez, H. Fouce (eds), Made in Spain: Studies in Popular Music, London, Routledge, p. 135-143.

Hilsdon A. M. (2007), « Transnationalism and agency in East Malaysia: Filipina migrants in the nightlife industries », The Australian journal of Anthropology, vol. 18, $\mathrm{n}^{\circ} 2$, p. 172-193.

Hollands R. (2015), « Waiting for the Weekend? Nightlife Studies and the Convergence of Youth Transition and Youth Cultural Analyses », in D. Woodman, A. BennetT (eds), Youth Cultures, Transitions, and Generations, London, Palgrave Macmillan, p. 69-83.

Kyba C.C., Pritchard S.B., Ekirch A.R., Eldridge A., Jechow A., Preiser C., Kunz D., Henckel D., Hölker F., Barentine J., Berge J., Meier J., Gwiazdzinski L., Spitschan M., Milan M., Bach S., Schroer S., Straw W. (2019), « Night Matters - Why the Interdisciplinary Field of 'Night Studies' is Needed », J: Multidisciplinary Scientific Journal, vol. 3, n 1, p. 1-6.

Lovatt A., O’Connor J. (1995), "Cities and the Night-time Economy », Planning Practice and Research, vol.10, $\mathrm{n}^{\circ}$ 2, p. 127-134.

MacArthur-Seal D. J. (2017), "Intoxication and Imperialism: Nightlife in Occupied Istanbul, 1918-1923 », Comparative Studies of South Asia, Africa and the Middle East, vol. $37, \mathrm{n}^{\circ} 2$, p. 299-313.

Mahler J. (1977), Ladies and Gentlemen, the Bronx Is Burning: 1977, Baseball, Politics, and the Battle for the Soul of a City, New York, Picador.

NoFRE, J., EldRidGe A. (eds) (2018), Exploring Nightlife: Space, Society erGovernance, London, Rowman \& Littlefield International.

Parrenas R. S. (2006), « Trafficked-Filipino Hostesses in Tokyo’s Nightlife Industry », Yale JL ef Feminism, vol. 18, p. 145-180.

Petra-Ramet S. (2018), Balkan Babel: The Disintegration of Yugoslavia From the Death of Tito to the Fall of Milosevic, New York, Routledge.

Phụng V. T. (2011), Luc Xì: Prostitution and Venereal disease in Colonial Hanoi, Honolulu, University of Hawaii Press. 
Quijano A. (2000), « Coloniality of Power, Ethnocentrism, and Latin America », Nepantla, vol. $1, \mathrm{n}^{\circ} 3, \mathrm{p} .533-580$.

ReEd I. A. (2019), "The King's Two Bodies and the Crisis of Liberal Modernity », The Hedgehog Review, vol. 21, n³, p. 56-78.

Shaw R. (2018), The Nocturnal City, New York, Routledge.

Song H., Pan M., Chen Y. (2016), « Nightlife and Public Spaces in Urban Villages: A Case Study of the Pearl River Delta in China », Habitat International, vol. 57, p. 187-204.

Sousa Santos B. de (2010), Epistemologias del Sur, México DF, Siglo XXI.

VAADAL K. (2019), « Navigating Nightlife: Women's Discourses on Unwanted Attention in Nightlife Settings in Norway ", Gender, Place ef Culture. A Journal of Feminist Geography, p. 1-21.

Volvey A., Calbérac Y., Houssay-Holzschuch M. (2012), "Fielding the (Geographical) Subject », Annales de Géographie, vol. 687-688, n 5, p. 441-461.

Yeo S. J., Ho K. C., Heng C. K. (2016), « Rethinking Spatial Planning for Urban Conviviality and Social Diversity: a Study of Nightlife in a Singapore Public Housing Estate Neighbourhood», Town Planning Review, vol. 87, n 4, p. 379-399.

ZENG G. (2009), « The Transformation of Nightlife Districts in Guangzhou, 1995-2009: Globalization, Dynamism, and Control », Chinese Sociology er Anthropology, vol. 42, $\mathrm{n}^{\circ} 2$, p. 56-75. 